ENTREPRENEURSHIP AND SUSTAINABILITY ISSUES

ISSN 2345-0282 (online) http://jssidoi.org/jesi/ 2020 Volume 8 Number 1 (September) http://doi.org/10.9770/jesi.2020.8.1(77)

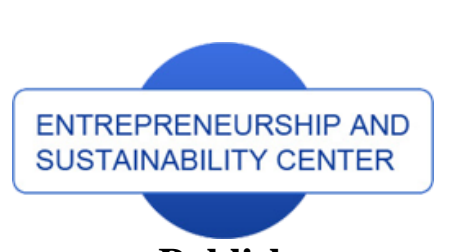

Publisher

http://jssidoi.org/esc/home

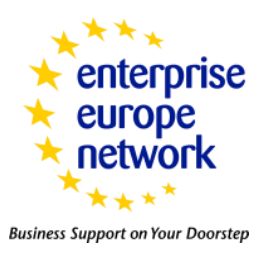

\section{Web of Science}

\section{CASPA Scopus'}

1 Clarivate

Analytics

\title{
A REVIEW OF THE EUROPEAN UNION FINANCIAL INSTRUMENTS SUPPOTING THE INNOVATIVE ACTIVITY OF ENTERPRISES IN THE CONTEXT OF INDUSTRY 4.0 IN THE YEARS 2021-2027 ${ }^{1}$
}

\author{
Joanna Wyrwa \\ Faculty of Economics and Management University of Zielona Góra, ul. Podgórna 50, 65-246 Zielona Góra, Poland \\ E-mail:j.wyrwa@wez.uz.zgora.pl
}

Received 23 February 2020; accepted 10 July 2020; published 30 September 2020

\begin{abstract}
The new global wave of disruptive innovations, which is based on the evolution of the industrial sector towards Industry 4.0, requires support for investments increasing the indicators of digitization, automation and robotization of enterprises. That is why one of the most important contemporary challenges facing enterprises in the context of Industry 4.0 is finding sources of financing to support innovative activities. Although the literature is abundant in studies on Industry 4.0. development, relatively little attention has been paid to the ways of financing these ventures or to a political environment that would favor the financing of the Fourth Industrial Revolution. The purpose of this article is therefore to identify EU financial instruments promoting business innovation in the context of Industry 4.0 in the years 2021-2027. The article was based on a systematic review of the literature and documents of the European Commission. In line with the adopted methodology, the entire research process consisted of three stages: (1) isolating databases and a set of publications, (2) selecting publications, developing a database, (3) bibliometric analysis, content analysis and testing relevance of results for further research.
\end{abstract}

Keywords: EU financial instruments; innovative activity; financial framework 2021-2027; Industry 4.0, systematic literature review

${ }^{1}$ The article is the result of the researches performed, partially financed by the University of Zielona Gora, within the competition called Small Grants.

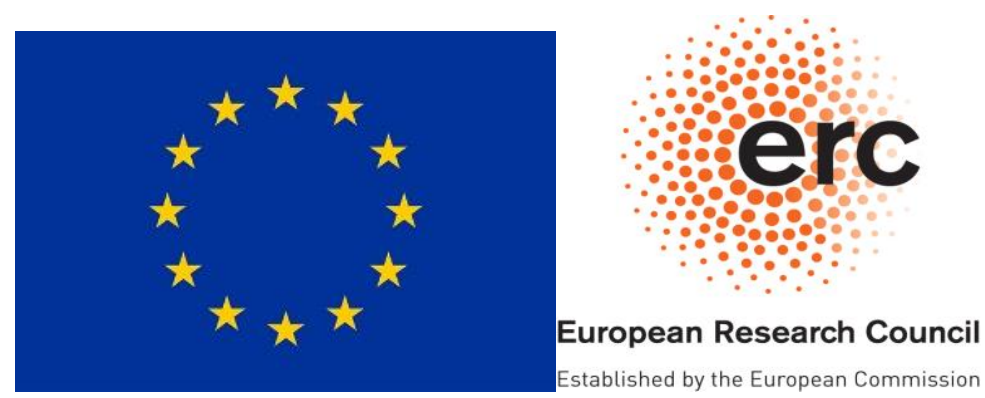




\section{ENTREPRENEURSHIP AND SUSTAINABILITY ISSUES}

ISSN 2345-0282 (online) http://jssidoi.org/jesi/

2020 Volume 8 Number 1 (September)

http://doi.org/10.9770/jesi.2020.8.1(77)

Reference to this paper should be made as follows: Wyrwa, J. 2020. A review of the European Union financial instruments supporting the innovative activity of enterprises in the context of Industry 4.0 in the years 2021-2027. Entrepreneurship and Sustainability Issues, 8(1), 1146-1161. http://doi.org/10.9770/jesi.2020.8.1(77)

JEL Classifications: L16, O31, O33, O38

\section{Introduction}

Innovation in all forms is a key factor that allows the European Union (EU) to continue to ensure the prosperity of its citizens and to face future challenges. Implementation of innovations requires a systemic, cross-cutting and multi-faceted approach. Economic progress, social well-being and the quality of life in Europe are based on its ability to boost productivity and growth, which in turn depends largely on its innovativeness. Innovation is also key for addressing the main challenges facing the EU. Broadly understood innovation is crucial in planning EU development but is also challenging for EU institutions. Currently, innovation is marked by a significant increase in the use of new technologies as well as changes in productivity and efficiency. A system of institutional support for innovation has emerged in the EU, with EU innovation policy being implemented through a variety of financial programs and instruments. Innovation policy is the link between research and technological development policy and industrial policy, including aspects such as: strengthening links in the innovation system, shaping and developing the capacity to introduce innovations (in the technical and technological field, as well as for organization and education), optimal use of innovation as a base factor for economic growth, and increasing the number of sustainable jobs, making structural changes of technical, technological and qualitative nature within industry. In recent years, innovation policy has undergone an evolution in which goals were redefined and various instruments of influence were created. Implementing innovation policy, and therefore intervening in research and development and innovation, has traditionally been justified by market failures. Nowadays, however, it is emphasized that it is system failures standing in the way of shifting to new technological structures that give innovation policy a foothold. EU innovation policy is complex and multi-faceted, requiring the design (preparation) and use of a broad range of instruments which, based on their function, can be divided into those facilitating the spread of innovation, conducive to the process of creating and implementing new knowledge, and acting as support mechanisms. The advantage of EU innovation policy tools is primarily the creation of an integrated system to boost innovation and its diffusion between science and business.

Over the past decades, new markets of global outreach have emerged for healthcare, media, entertainment, communication and retail thanks to breakthrough innovations in ICT, biotechnology, green technologies, the Internet and the platform economy. This marks a new global wave of disruptive innovations that will be based on more advanced technologies (such as "deep tech"), among them: blockchain technology, artificial intelligence, genomics/multi-omics, robotics, and other technologies which also can be created by individual innovators and or a community of citizens. The common denominator of such innovations is that they cut across various scientific disciplines, technological solutions and economic sectors, offering radically new combinations of products, processes, services and business models; they also have the potential to open entirely new markets around the world.

Having said all that, innovations require special measures at EU level that will greatly improve the conditions and environment for developing European innovations, so that new ideas and technologies can be freely exchanged by actors in the innovation ecosystem and be therefore quickly transformed into products and services allowing the EU to achieve its goal. This poses a number of challenges for innovation policy, which should be able to respond flexibly to emerging issues and technological trends. Another challenge is the transformation of the economy towards what is referred to as "Industry 4.0", which takes into account the evolution of the industrial sector consisting in the increasing reliance on data that becomes a value-creating production resource. To that end, investments must be supported that increase the indicators of digitization, automation and robotization of enterprises (European Commission 2017). A new perspective on EU industrial policy was set out already in the 


\section{ENTREPRENEURSHIP AND SUSTAINABILITY ISSUES}

ISSN 2345-0282 (online) http://jssidoi.org/jesi/ 2020 Volume 8 Number 1 (September) http://doi.org/10.9770/jesi.2020.8.1(77)

Europe 2020 strategy (European Commission 2010a), and more specifically in one of its seven flagship initiatives entitled An Integrated Industrial Policy for the Globalisation Era (European Commission 2010b). In that document, the need is signaled to return to a strong industrial policy in the EU which would address manufacturing and by extension services, a proposal justified by the changing geopolitical situation and the need to recover lost industry against the rising production costs in the Far East. The same document also mentions the Fourth Industrial Revolution, postulating support for the creation of a solid and sustainable industrial base able to compete in global markets. The very term Fourth Industrial Revolution is a reference to other groundbreaking events in the socio-economic development of mankind such as: mechanization of production using water- and steam-powered machines (Revolution 1.0), the introduction of mass production based on the division of labor and the electrification of machinery and equipment (Revolution 2.0 ), and the use of electronics and IT for the automation of production (Revolution 3.0). The First Industrial Revolution, which began in the second half of the eighteenth and continued throughout the nineteenth century, introduced mechanical production equipment and initiated the use of water energy. The Second Industrial Revolution, dating back to the 1870s, involved the use of electricity and mass production in factories. The Third Industrial Revolution, also known as the Digital Revolution, can be traced back to the 1970s when advanced electronics and information technology enabled automation of production processes (Hermann et al. 2015, p. 5). The Fourth Industrial Revolution has its roots in the German Industrie 4.0 initiative from 2011 whose aim was to strengthen the competitiveness of the manufacturing industry (Issa et al. 2018, p. 973). The goal of the Fourth Industrial Revolution is operation at a higher level of automation, achievement of a higher level of operational productivity by linking the physical with the virtual world, and digitization of various production processes. This new revolution is marked by three particular characteristics (Paprocki 2016, p. 40): (1) universal digitization and ensuring constant communication (people among themselves, people with devices, and devices among themselves), (2) frequent implementation of disruptive innovations (allowing a rapid increase in the efficiency and effectiveness of the socio-economic system), (3) developing a generation of machines capable of autonomous behavior (through artificial intelligence used to control them). The Fourth Industrial Revolution is therefore assumed to have at its core the use of scientific and technological achievements to allow the emergence of Industry 4.0.

Industry 4.0 is an increasingly common topic of deliberations not only in business environments or in the context of economic policy, but also in scientific discourse, as evidenced by the rapidly growing number of publications in renowned journals (Oesterreich \& Teuteberg 2016; Liao et al. 2017; Lu 2017). In the literature, the benefits of Industry 4.0 solutions seem to be emphasized particularly often, which - although in many case supported by reallife examples of successful projects - are indicative of a somewhat idealized state of harmonized digital transformation. However, some studies (e.g. Dmowski et al. 2016; McKinsey Digital 2016; PwC 2016; PwC 2017) clearly point to uncertainty among enterprises as to what the implementation of Industry 4.0 technologies actually requires on their part. Let us also note that the implementation of the Industry 4.0 concept will be supported mainly by innovative projects marked by a high level of uncertainty of outcomes, a complexity of implemented measures and an overall higher risk. To meet the upcoming challenges, organizations will have to find new ways of financing innovative projects - that is why raising funds will be one of the main challenges for them once Industry 4.0 has settled in. Although the literature is abundant in studies on Industry 4.0. development, relatively little attention has been paid to the ways of financing these ventures or to a political environment that would favor the financing of the Fourth Industrial Revolution. The purpose of this article is therefore to identify EU financial instruments promoting business innovation in the context of Industry 4.0 in the years 2021-2027. To achieve this goal, the following research question was posed: What is the current state of knowledge of the support instruments for improving business innovation in the new EU financial framework 2021-2027 in the context of the development of Industry 4.0? The article was based on a systematic review of the literature and documents of the European Commission. Systematic review methodology allows not only for a formalized and objectified synthesis of the current scientific achievements and the evaluation of existing research studies (Columb \& Lalkhen 2005), but more importantly, it enables identification of both researched and unexplored areas (Levy \& Ellis 2006). This, in turn, provides a framework for further research (Gimenez \& Tachizawa 2012) 


\section{ENTREPRENEURSHIP AND SUSTAINABILITY ISSUES}

ISSN 2345-0282 (online) http://jssidoi.org/jesi/ 2020 Volume 8 Number 1 (September) http://doi.org/10.9770/jesi.2020.8.1(77)

whose future results can be generated in global literature. The article was structured so as to best achieve the research goal.

\section{Methodology}

The study used systematic literature review, which is defined as "a review subject to a clearly defined question, using explicit methods for the identification, selection and critical evaluation of relevant studies, and the collection and analysis of data from studies qualified for that review" (Booth et al. 2016). The advantage of systematic compared to traditional (often subjective and incomplete) literature review is the fact it poses research questions prior to commencing proper analysis, meaning it compiles beforehand a full list of relevant works along with the criteria for inclusion or exclusion of particular literature items. The structured form also generates new knowledge about the current state of science in the field at issue. This is particularly important when a necessity arises to account for the significant dispersion of publications in both printed periodicals and online sources. The systematic literature review procedure included the following stages (Rowley \& Slack 2004; Piccarozzi et al. 2018): defining research purpose, separating and selecting primary literature, selecting publications, developing a publication database, analyzing content and testing relevance of results for further research (Fig. 1).

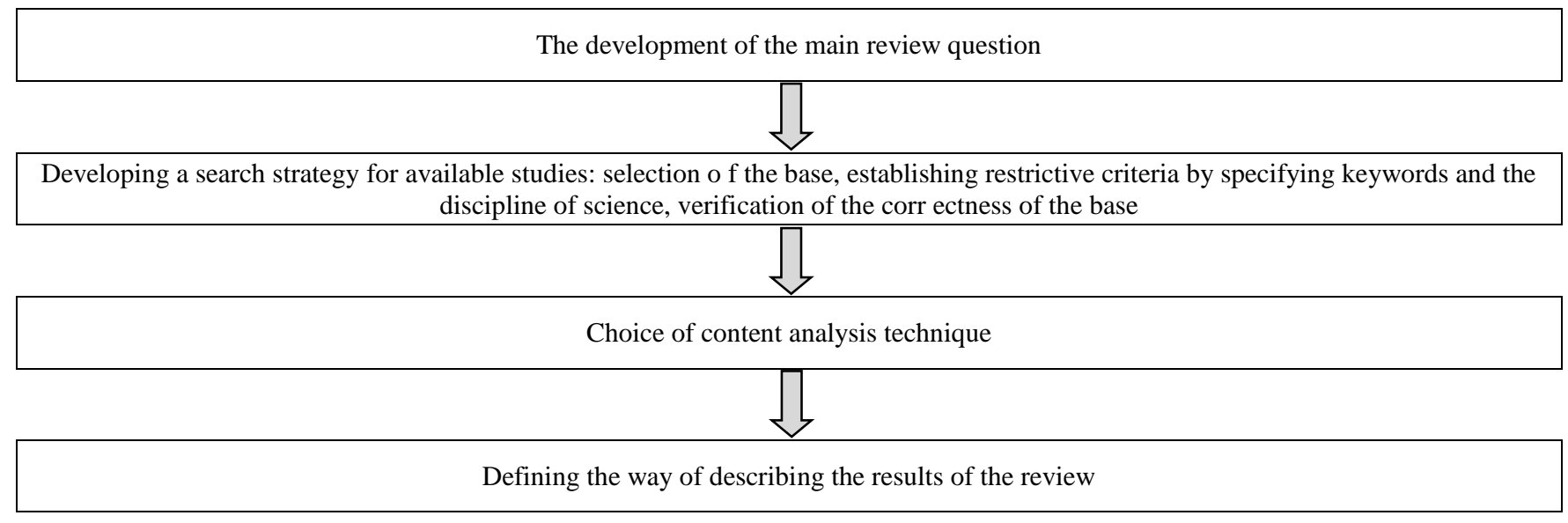

Fig. 1. Stages of literatur review

Source: own study based on: Bałandynowicz-Panfil 2019, p. 73

Given the adopted procedure, databases were selected and subsequently analyzed in the first stage. The process of creating the literature database was based on three international electronic databases: Ebsco, Proquest, and the Web of Science. These three databases contain journals and books by recognized international publishers and come equipped with advanced search engines where keywords can be filtered along with several additional criteria. The databases are a popular resource and many universities around the world have access to them. In addition, they are recommended for conducting systematic literature reviews in social sciences. It was assumed that the search criteria should be included in the title, abstract or keywords of the analyzed works. This assumption helped focus attention on those articles whose key slogan reflects an important research category rather than an accessorial one. The process of creating a literature database envisaged the use of a mixed approach in which academic literature indexed in scientific databases is reviewed alongside grey literature (Benzies et al. 2006). In doing so, an important possibility opened up of including European Commission documents and the latest publications of a less scientific nature. The following restrictions have been imposed on the identified publications: (1) full-text, peer-reviewed publications, (2) "EU financial instruments", "innovative activity", "financial framework 2021-2027" and "Industry 4.0" in the title and keywords, (3) pertaining to the field of social sciences. It was assumed that the selected literature would cover the years 2016-2020. The thus obtained database 


\section{ENTREPRENEURSHIP AND SUSTAINABILITY ISSUES}

ISSN 2345-0282 (online) http://jssidoi.org/jesi/

2020 Volume 8 Number 1 (September)

http://doi.org/10.9770/jesi.2020.8.1(77)

of publications was further analyzed. The collected literature database was thoroughly analysed. To describe the results, a narrative method was adopted whose main purpose was to indicate the pivotal areas of exploration of the subject matter at hand.

The use of systematic literature review sprang from the need to indicate the complexity of the issues raised. This method is justified when a research area has been strongly explored, which makes it appropriate to present a synthesis of the results of literature studies. Nevertheless, this approach to literature review has certain limitations resulting mainly from the imperfections of the analysis methods used. At the stage of creating the literature base, the adopted restrictions may have had an impact on the results obtained. Meanwhile, at the review stage, the restrictions concerned the imperfections of content analysis, namely the subjectivity of the content researcher. It should also be noted that the results of the query are merely a snapshot of the current state of knowledge at a given moment whereas knowledge as such is dynamic.

\section{Literature review}

\section{The idea behind the Industry 4.0 concept}

The term "Industry 4.0" was coined in 2010 during a project launched by the German government to identify and analyze the then upcoming groundbreaking changes of strategic importance to the German economy Defined as Industry 4.0, this German initiative comes from the general direction of changes in the EU's industrial policy and builds on concepts such as: the Industrial Internet of Things, smart industry, smart factories, resilient factories or advanced manufacturing. In 2011, at the Hanover Fair, the term was used for the first time in presentations debating on the future of industry. In 2013, the working group made up of German business, industry and science experts published a document containing recommendations for the implementation of what was called an INDUSTRIE 4.0 Strategic Initiative, providing a glimpse into a new cyber-physical reality shaped by revolutionary changes in industry. The term "Industry 4.0" was also used in the German government's technology development project High-Tech Strategy 2020 whose one of the key areas was identified as "digital economy and society" (Astor 2016; Astor 2017; Astor 2019).

Industry 4.0 (Müller et al. 2017) is defined in many different ways in the literature and that is because it can be described and explained equally at micro- (enterprise), meso- (sector) or macro-level (the economy as a whole). A recurring theme in all these definitions, however, is the integration of people, machines and advanced communication and information technologies, enabling real-time interaction between the key components of a (manufacturing or service) enterprise, a sector and the economy (Młody 2019; Młody \& Weinert 2020). Industry 4.0 technologies form an open set due to the combinations of solutions and their derivatives being permanently developed by manufacturers and users alike (Batkovskiy et al. 2019). When defining Industry 4.0, different approaches seem to agree on the important role the digitization of production (manufacturing) plays in all this, given that it involves a broad range of technical innovations in areas such as: generation, transfer and processing of data, analytics of large data resources, connection and integration of the virtual with the real world, new production technologies, new materials (Astor 2016). In broader terms, 4.0 should be seen as a collective term for technologies and concepts of value chain organization (Hermann et al. 2015, p. 11). Information and data correlation are used in Industry 4.0 all the time and everywhere. Industry 4.0 is a form of unification of the world of machines with the virtual world of the Internet (also the Internet of Things) and information technology (Gajdzik \& Grabowska 2018, p. 223). Industry 4.0 binds machines into a network encompassing production resource management systems and production planning (Gajdzik \& Grabowska 2018, p. 223). The resulting production system springs from the dissemination and distribution of automatic technology and online communication networks.

According to Castelo-Branco et al. (2019, p. 22) Industry 4.0 is a concept that represents "the adoption by industrial companies of techniques and processes allowed by digitization, cloud computing, the internet of things 


\section{ENTREPRENEURSHIP AND SUSTAINABILITY ISSUES}

ISSN 2345-0282 (online) http://jssidoi.org/jesi/ 2020 Volume 8 Number 1 (September) http://doi.org/10.9770/jesi.2020.8.1(77)

and big data to gain competitive advantages in domestic and global markets". Additionally, Barreto et al. (2017, p. 1247) argue that, in an organizational structure point of view, Industry 4.0 "includes horizontal integration through networks in order to facilitate an internal cooperation, vertical integration of subsystems within the factory in order to create a flexible and adaptable manufacturing systems and through-engineering integration across the entire value chain to enable customization of the product". In turn, Chiarello et al. (2018, p. 247) define Industry 4.0 in the context of Porter's value chain and point to the use of various technologies typical of Industry 4.0 in areas such as: production, internal logistics, orders, maintenance, external logistics, distribution and sales, as well as after-sales services. This last approach to Industry 4.0 shows that it is a concept that goes significantly beyond merely production to cover both organization and coordination of all processes within the value chain, including service processes.

The essence of Industry 4.0 is to create smart value chains based on dynamic, self-organizing and optimizing social-engineering systems known as smart factories. These factories will consist of spontaneously emerging virtual networks covering employees, machines, devices and supporting IT systems. Together they will form a dynamic network centered around a common object of cooperation and constantly reconfigured against changing goals and conditions. It is assumed that this new organization of work will ensure high flexibility and performance, while the virtualization of economic processes should enable access to group intelligence by initiating, creating and applying knowledge within informal knowledge networks (e.g. open innovation, communities of practice) and also to specialist knowledge without the need to hire external specialists. For Industry 4.0 to be implemented successfully, a makeover of industrial enterprises' operating model is inevitable (Bendkowski 2017, p. 24).

The concept of Industry 4.0 emerged with a view to fully tapping into the possibilities of the Internet and information technologies to create smart factories by enabling the manufacturing of individual units in accordance with customized projects or specific customer needs. Efforts are made to accelerate the adaptation of systems to changing market preferences and to minimize emergencies, increase the efficient use of resources and energy and extend the production process to include suppliers and recipients (in the supply chain) while effectively sharing employee knowledge, competence and innovation (based on new models of cooperation with partners). The combination of production resources, both internal and external, is intended to create a smart value chain network that can be autonomously controlled and in which smart processing of matter occurs. Therefore, the main idea behind the Industry 4.0 concept is a shift from mass production towards on-demand production aligned with customer needs. This is in response to the current needs of companies to adapt operations to customer requirements in terms of product customization (Niedbał et al. 2017, p. 559).

The concept of Industry 4.0 has been based on the latest digital technologies while its goal is to put forward a new industry model consisting primarily in the cooperation of several entities, i.e. not only between production plants themselves but across various actors involved in the entire cooperation chain - from product design to after-sales services. This model was inspired by the idea of creating a two-level interconnected area of operation, or a cyberphysical production system. In that model, physical production processes are reflected in digital reality to allow optimization of all activities from idea and design, through the use of raw materials and energy, to customizable production process control, logistics, marketing and recycling - all this while factoring in horizontal and vertical cooperation chains at different stages of operation with different entities that may be involved at any time and anywhere. The bridge linking these two worlds (physical and digital) is data transferred via the Internet from the level of physical activities to the sphere of digital reality, and vice versa, but also to and from other potentially involved external entities. Industry 4.0 is not just about plant performance; it goes far beyond that, spanning across the entire ecosystem of the production process thanks to digital transformation.

The Industry 4.0 concept is geared towards a high productivity of industrial systems and a high profitability of implemented projects. Particularly noteworthy among its potential benefits are increased production flexibility 


\section{ENTREPRENEURSHIP AND SUSTAINABILITY ISSUES}

ISSN 2345-0282 (online) http://jssidoi.org/jesi/ 2020 Volume 8 Number 1 (September) http://doi.org/10.9770/jesi.2020.8.1(77)

and organization of more customized production. This means that customer expectations - the customer being a product user - can be met without compromising the profitability of the production process by means of dynamic matching of the autonomous modules of the entire process of preparation, manufacturing and delivery of the product to the customer using IoT and information stored in Big Data and Cloud Computing (Chui et al. 2010). Industry 4.0 is therefore a combination of the benefits of customized production with the benefits offered already today by mass production. It may also significantly improve production performance through the use of material, manufacturing and employee resources from cooperating network partners with unused production capacity (Saniuk \& Saniuk 2017, p. 13). The concept of Industry 4.0 fits perfectly into the European economic model. It will make it possible to maintain sustainable industry, develop employee qualifications, support energy transformation and adapt to a high level of customization. Industrial robots and information and communication technologies (ICT) will facilitate the integration of work from design, through supply and logistics, to final product whose quality will be the result of support and optimization programs cooperating with humans acting as "guardians of quality" on automated production lines (Stolarczyk 2017, p. 75). Industry 4.0 will also allow Europe to successfully compete with other regions. The high complexity and comprehensiveness of innovative processes related to Industry 4.0 will make it is necessary to introduce a holistic set of complementary financial instruments supporting the implementation of these novel solutions.

\section{Results and discussion}

\section{European Union innovation policy instruments in the context of developing fourth-generation industry}

Horizon Europe (European Commission 2018a) will be the most important financial instrument supporting the innovative activity of enterprises in the new perspective. In the opinion of the European Commission, this is the most ambitious research and innovation program in the history of the EU. Equally impressive is its budget for 2021-2027, which is set at EUR 100 billion. Horizon Europe will build on the achievements and successes of the previous Horizon 2020 research and innovation program and will ensure that the EU maintains a leading position in the world in this field. Horizon Europe's main goal is to strengthen the EU as one of the main global leaders in research and innovation. In particular, the Program's objectives include: (1) strengthening the EU's and the European Research Area's scientific and technological base, (2) increasing EU capacity for innovation, competitiveness and number of jobs, and (3) implementing citizens' priorities and maintaining the European socio-economic model with its underpinning values. Of the proposed budget of EUR 100 billion, EUR 97.6 billion is to be allocated to Horizon Europe (of which EUR 3.5 billion will be allocated to the InvestEU Fund) and EUR 2.4 billion to the Euratom program. The Euratom (European Commission 2018b) will fund research and training in the areas of nuclear safety, nuclear physical security and radiological protection. The program will be more focused on non-energy applications such as health care and medical equipment, and will support the mobility of nuclear scientists as part of the "Maria Skłodowska-Curie" Actions.

Horizon Europe is expected to bring new and broader knowledge, and also new and more technologies, as well as to promote scientific excellence and have a positive impact on growth, trade and investment, plus a significant impact on society and the environment. Every euro invested under this program can generate a return of up to EUR 11 of GDP over a 25-year period. It can be expected EU investments in research and innovation will lead directly to the creation of an estimated 100,000 jobs in the research and innovation sector in the "investment phase" (2021-2027). To reflect the great importance of combating climate change in line with the EU's commitment to implement the Paris Agreement and achieve sustainable development goals, Horizon Europe will seek to mainstream climate change at a political level, allocating for that purpose at least $35 \%$ of its total financial envelope.

The Horizon Europe framework program rests on three interconnected, mutually complementary pillars (Fig. 2.). Pillar 1, "Excellent Science", will support the excellence of research in the field of basic sciences and strengthen the scientific primacy of the EU, and will help develop high-quality knowledge and skills. Pillar 2, "Global 
Challenges and European Industrial Competitiveness", will support research on social challenges and industrial technologies in areas such as health, security, digital technologies and key enabling technologies, climate, energy, mobility, food and natural resources. The first pillar will be available only to the world of science, while the second pillar will target mainly enterprises and industry. Each research mission will contain a portfolio of research activities. Pillar 3, "Innovative Europe", will focus on increasing the number of disruptive and radical innovations by establishing a European Innovation Council (EIC) which will offer comprehensive services to high-potential innovators. The third pillar will be addressed in particular to the SME sector. New to the Horizon 2020 Framework Program will be EU-wide research and innovation missions intended to reflect the impact of social engagement on research agendas. The missions comprise specific sets of interdisciplinary activities focusing on social challenges and industrial competitiveness. The Horizon Europe program has outlined five areas in which missions will be programmed under the "Global Challenges and European Industrial Competitiveness" pillar, drawing from contributions from the other pillars. Mission areas are: (1) adaptation to climate change, including social transformation, (2) cancer, (3) climate-neutral and smart cities, (4) healthy oceans, seas, coastal and inland waters, (4) soil health and food. In addition, institutionalized partnerships will be established under which public-private consortia will be created to carry out joint research and development aimed at strengthening specific industrial sectors.

\begin{tabular}{|c|c|c|}
\hline $\begin{array}{c}\text { Pillar 1 } \\
\text { Excellent Science }\end{array}$ & $\begin{array}{l}\text { Pillar } 2 \\
\text { Global Challenges and European } \\
\text { Industrial Competitiveness }\end{array}$ & $\begin{array}{c}\text { Pillar } 3 \\
\text { Innovative Europe }\end{array}$ \\
\hline $\begin{array}{c}\text { European Research Council } \\
\text { Marie Skłodowska-Curie Actions } \\
\text { Research Infrastructures }\end{array}$ & $\begin{array}{l}\text { Clusters: } \\
\text { - Health } \\
\text { - Culture, Creativity and Inclusive } \\
\text { Society } \\
\text { - Civil Security For Society } \\
\text { - Digital, Industry and Space } \\
\text { - Climate, Energy and Mobility } \\
\text { - Food, Bioeconomy, Natural } \\
\text { Resources, Agriculture and } \\
\text { Environment } \\
\text { Joint Research Centre }\end{array}$ & $\begin{array}{c}\text { European Innovation Council } \\
\text { European Innovation Ecosystems } \\
\text { European Institute of Innovation } \\
\text { and Technology }\end{array}$ \\
\hline
\end{tabular}

Widening Participation and Strengthening the European Research Area

Widening Participation and Spreading Excellence

Reforming and Enhancing the European R\&I system

Fig.2. Preliminary Horizon Europe Structure - The Research and Innovation Framework Programme FP9 (2021-2027) Source: European Commission (2019)

The EIC will become one of the crucial mechanisms supporting innovation under the Horizon Europe. The EIC will offer support in the quest for the EU to become a leader in innovation-creating markets. To this end, the EIC will act as a comprehensive service point for innovators producing disruptive technologies with high potential, as well as to innovative enterprises with growth potential. Depending on the structure, it will provide support to individual beneficiaries and multidisciplinary consortia. The EIC will primarily promote disruptive and revolutionary technologies and innovations, focusing to a large extent on market-creating innovations. The EIC 


\section{ENTREPRENEURSHIP AND SUSTAINABILITY ISSUES}

ISSN 2345-0282 (online) http://jssidoi.org/jesi/ 2020 Volume 8 Number 1 (September) http://doi.org/10.9770/jesi.2020.8.1(77)

will identify and finance high-growth, high-risk innovations who have the potential to create completely new markets, while supporting all types of innovation, including disruptive and radical innovations such as deep tech, that have the potential to become market-created innovations. In addition, the EIC will seek to rapidly expand the scale of operations of innovative enterprises, mainly SMEs, including start-ups, and, in exceptional cases, small mid-cap companies, at both EU and international level, on the path from the idea to the market. The EIC will work against a budget of EUR 2.7 billion in the pilot phase covering the $2018-2020$ period. This is to help define and develop on a large scale dynamic venture innovations with huge potential to create entirely new markets.

The EIC will operate primarily via two complementary types of activities: the "Pioneer" instrument for advanced scientific research in the early stages of technological development and the "Accelerator" instrument in the field of innovation and marketing activities, including stages before mass commercialization and business growth. Under the "Pioneer" instrument, support will be provided to research conducive to transformation and potential market-creating innovations. The Pioneer will provide grants for innovative venture projects dealing with new fields and areas of deep technologies, in order to develop potentially radical innovative technologies of the future and create new market opportunities. The overall goal of the Pioneer will be to help transform breakthrough solutions into potential market-creating innovations and bring them to the demonstration or business justification stage, or to develop a strategy that enables their further implementation under the Accelerator or as part of another market entry solution. To this end, the Pioneer will support the earliest stages of scientific research and development in the field of science and technology, including design validation and prototypes for technology validation. The instrument will be implemented mainly through collaborative research and in close coordination with other parts of the Horizon Europe program, in particular with the European Research Council (ERC), the "Maria Skłodowska-Curie" Actions (MSCA), a part of Pillar 3 on the European ecosystem and the activities of Knowledge and Innovation Communities (KICs) of the European Institute of Innovation and Technology (EIT) to identify radically new ideas and concepts that have a breakthrough potential. Meanwhile, the Accelerator will mainly grant two types of support - mixed financing (combining subsidies with capital investments), and subsidies, optionally supplemented with capital backing. It will also provide access to loans and guarantees, especially those granted under the InvestEU program. If already during the pre-selection ("due diligence" analysis) it is recognized that a project will bring profits, or if the level of risk is sufficiently reduced, the Accelerator will facilitate access to debt financing (e.g. loans or guarantees) and for equity financing from the InvestEU program. The EIC's Accelerator will also provide support in the form of grants to SMEs, including start-ups, for a variety of types of innovation, ranging from gradual innovations to disruptive and radical innovations, whose aim is to increase the scale of operations.

The activities of the EIC will complement the work of the European Institute of Innovation and Technology (Wilkinson et al. 2017a; Wilkinson et al. 2017b; European Commission 2008; European Commission 2013; European Commission 2019a; European Commission 2019b; European Commission 2019e). The EIT is an independent EU body founded in 2008 to increase Europe's innovation capacity. The EIT is one of the three components of the "Innovative Europe" pillar. The aim of the EIT is to meet the most important societal challenges by improving the EU's capacity and results in innovation through the integration of the knowledge triangle covering education, research, and innovation. At the core of the EIC lies the creation of the so-called Knowledge and Innovation Communities (KICs), which are the EIC's operational units, and transforming research findings into economic effects. The EIT currently supports eight KICs bringing together enterprises, universities and research centers that together form cross-border partnerships. Innovative KICs emerging from the KICs at the EIT may be directed to the EICs to create a "production line" of not yet profitable innovations, while innovative high-potential enterprises financed by EICs that are not yet involved in any of the KICs at the EIT may get access to this additional support. The proposed EIT budget for 2021-2027 is to amount to EUR 3 billion, which represents an increase of $25 \%$, or EUR 600 million, compared to the budget of the current Strategic Innovation Plan (2014-2020). This will help fund the existing and new Knowledge and Innovation Communities and also support the innovation capacity of 750 higher education institutions. With its proposed budget for 2021- 


\section{ENTREPRENEURSHIP AND SUSTAINABILITY ISSUES}

ISSN 2345-0282 (online) http://jssidoi.org/jesi/

2020 Volume 8 Number 1 (September)

http://doi.org/10.9770/jesi.2020.8.1(77)

2027 the Institute will boost innovation by supporting more than 10,000 graduates from its KICs' Master and PhDs, around 600 new start-ups and more than 7,000 existing ones. With a proposed budget of 3 billion, which represents an increase of 25\% compared to the current Strategic Innovation Agenda (2014-2020), the EIT will fund activities of existing and new Knowledge and Innovation Communities (KICs) and support the innovation capacity of 750 higher education institutions (European Institute of Innovation and Technology 2019).

Another important EU initiative supporting the innovative activity of enterprises in the years 2021-2027 is "A Renewed Agenda for Research and Innovation" (European Commission 2018c). This agenda is based on the assumption that research and innovation resources are an investment in the future of Europe and will allow the Union to maintain its competitive position and a unique European social model on a global scale. The renewed agenda covers a number of specific measures to increase innovation and ensure a high quality of life. These activities result from the fact that, despite significant development achievements in the economy, new megatrends appear (e.g. artificial intelligence or circular economy) that bring about huge changes in the economy and society. In the opinion of the European Commission, Europe is in need of reforms in the system of financing important disruptive innovations.

The Renewed Agenda (European Commission 2018c) arose due to the fact that, even though Europe generates $20 \%$ of global investment in research and development (with $7 \%$ of the world population), publishes one-third of high-class scientific publications and is a leader in industrial sectors such as pharmaceuticals, electronics, renewable energy, bio-industry or mechanical engineering, EU companies invest less in innovation than China (1.3\% of EU GDP vs. $1.6 \%$ in the PRC), the United States (2\% of GDP), Japan (2.6\% of GDP) and South Korea (3.3\% of GDP). Another worrying indicator is the number of headquarters of start-ups with a market value above USD 1 billion in the EU compared to other countries (26 in the EU, 109 in the United States, and 59 in China). Therefore, maintaining the EU's competitive position depends on increasing its innovation potential.

Another important EU instrument supporting innovation is the "Stairway to excellence (S2E)", which will continue to provide customized support and expertise to regions that are lagging behind in terms of innovation. This initiative was launched as part of a partnership with the European Parliament (EP) in 2014. For 2018-2019, the initiative has a budget of EUR 3 million. Its purpose is to provide support and expertise to those regions that show significant delays in implementing innovation. The initiative has two main objectives: (1) "finding" EU funds that will help finance innovative projects and cooperate with regions with a similar potential, and (2) jointly create innovative clusters. As part of the "Stairway to excellence", the agenda of the Science and Knowledge Committee, the Joint Research Center (JRC), will help regions not only tap into their priorities and strengths, but also offer guidance in the process of mutual transfer of knowledge between regions and in developing human creativity and talents. This initiative will help regions to develop, update and refine their smart specialization strategies - i.e. regional innovation strategies based on niche areas in which regions can demonstrate a competitive advantage - for the needs of the 2021-2027 budget period (Szatlach 2018, p. 598). It will also help them identify adequate EU resources to finance innovative projects, and pair up with other regions with similar assets to create innovation clusters. Following the Commission's proposals for the future Cohesion Policy, the new Horizon Europe programme, and in line with the Commission's renewed agenda for Research and Innovation, "Stairway to Excellence" is another way the Commission is helping Europe's regions prepare for the future, with solid innovation strategies supported by EU funds in the next long-term EU budget for 2021-2027.

To increase investment in innovative start-up and scale-up enterprises in Europe, the European Commission and European Investment Fund (EIF) (European Commission 2018d) have launched the VentureEU initiative, which is part of the wider ecosystem that is being introduced by the EU to enable many innovative European entrepreneurs to become global market leaders. In particular, as part of the Action Plan for a Capital Markets Union, the Commission presented a list of measures to improve access to finance for small and growing enterprises to develop and create jobs. The Investment Plan for Europe also aims to improve the business 


\section{ENTREPRENEURSHIP AND SUSTAINABILITY ISSUES}

ISSN 2345-0282 (online) http://jssidoi.org/jesi/

2020 Volume 8 Number 1 (September)

http://doi.org/10.9770/jesi.2020.8.1(77)

environment in the EU by making smarter use of financial resources and removing barriers to investment. The Commission and the EIF have announced six funds that will receive EU support through investment in the venture capital market. The funds, supported from EU funds in the amount of EUR 410 million, are to raise up to EUR 2.1 billion in public and private investment. This, in turn, is expected to trigger an estimated EUR 6.5 billion of new investments in innovative start-ups and scale-ups across Europe, thereby doubling the amount of venture capital currently available in Europe. While venture capital (VC) is important for a thriving capital markets union, it remains largely underdeveloped in Europe. In 2016, venture capital investors invested around EUR 6.5 billion in the EU, compared with EUR 39.4 billion invested by the United States. Furthermore, VC funds in Europe are too small - an average of EUR 56 million in the EU, compared with 156 million in the US. As a result, the companies are moving to ecosystems where they have better chances for rapid development. The number of enterprises that managed to work out a market value of over USD 1 billion by the end of 2017 was 26 in the EU, compared to 109 in the US and 59 in China.

VentureEU will provide new sources of financing, giving European innovators the opportunity to become leading global companies. About 1,500 start-ups and scale-ups across Europe are expected to gain access to funds. The EU will provide output investments worth up to EUR 410 million, including EUR 67 million from EIF own resources: EUR 200 million under the Horizon 2020 InnovFin capital instrument, EUR 105 million from the COSME (Europe's program for small and medium-sized enterprises) and EUR 105 million from the European Fund for Strategic Investments (EFSI) - the so-called Juncker Plan. The remaining financing will be collected by selected fund managers, mainly from independent investors. The six funds will invest in several smaller investment funds, covering projects in at least four European countries. Invested funds will help finance SMEs and mid-cap companies from a variety of sectors, such as information and communication technologies (ICT), digital technologies, life sciences, medical technologies, and resource efficiency and energy efficiency. The EU investment in VentureEU will be managed by the EIF under the control of the Commission. It will be introduced by six professional and experienced fund managers providing an approach based entirely on market mechanisms. This will attract more investment and significantly increase the availability of VC financing for start-ups and scale-ups in Europe.

Investing in research and innovation means investing in the future of Europe, knowledge and new solutions allowing to maintain sustainable economic growth and make the economy more competitive. Therefore, the new Strategic Innovation Agenda (SIA) for 2021-2027 (European Commission 2019c; European Commission 2019d; European Commission 2019e; European Commission 2019f) has the following assumptions:

- increasing the impact of knowledge and innovation communities at a regional level - the EIT will strengthen its networks, engage more higher-education institutions, enterprises and research organizations, and develop strategies for regional coverage. KICs will also develop links to smart specialization strategies;

- increasing the innovation capacity of higher education - the EIT will support 750 higher -education institutions in the form of financial resources, expertise and training. The Institute will develop and launch activities mainly in countries with lower innovation capacities. To this end, the EIT will benefit from successful initiatives such as HEInnovate, i.e. a free self-assessment tool for all types of higher-education institutions, or a regional innovation impact assessment framework that allows universities to assess how they support innovation in regions where they are present;

- creation of new KICs - the EIT will launch two new KICs, selected in areas most relevant to the priorities of the Horizon Europe program. The first new KIC is to be created in 2022 and will focus on the cultural and creative sectors. The second new KIC is to be launched in 2025 and the decision on its priority area will be made at a later stage. 


\section{ENTREPRENEURSHIP AND SUSTAINABILITY ISSUES}

ISSN 2345-0282 (online) http://jssidoi.org/jesi/ 2020 Volume 8 Number 1 (September) http://doi.org/10.9770/jesi.2020.8.1(77)

\section{Conclusions}

An important source of finance for Industry 4.0 projects are EU programs. Supporting these projects is one of the priorities set out in EU development policy, with the EU aiming to spread the embrace of Industry 4.0 throughout its territory. Particularly noteworthy are initiatives such as the establishment of the European Research Area (ERA) or the European Institute of Innovation and Technology (EIT), the allocation of increasing funds for research and innovation in the Framework Programs, developing the mobility of researchers and students, creating European technology platforms, supporting smart specializations and sectoral approach (clusters of enterprises from across the EU), supporting the development of e-administration and the Digital Single Market, promoting Open Science and Open Innovation, stimulating the creation of pan-European venture capital, supporting the development of industry infrastructure (ICT, energy and transport networks), and finally, adopting legal regulations which protect intellectual property and personal data as well as promoting European standardization.

Strengthening innovation activities in the EU is becoming one of the paths for rebuilding the European economy and improving Europe's competitiveness in the global economy. This poses new challenges for the EU's industrial policy for 2021-2027 regarding its objectives, instruments and mechanisms for research, technological development and innovation. Particular attention is being paid to the effectiveness and efficiency of the instruments employed at the level of EU innovation policy. The need to devise an appropriate innovation ecosystem is emphasized. It is especially important to put forward institutional framework conditions for the creation and diffusion of innovation among the Member States, which would be conducive to the implementation of effective innovation systems at European, national and regional level, all while being mutually complementary and allowing the synergy effect. The European Commission's initiatives aimed at increasing efficiency in research, boosting innovation and developing modern technology markets reflect the right shift in EU innovation policy.

\section{References}

Astor (2016). Przemyst 4.0. Rewolucja już tu jest. Co o niej wiesz? [Industry 4.0. The revolution is already here. What do you know about it?]. Astor Whitepaper, from https://www.astor.com.pl/images/Industry_4-0_Przemys1_4-0/ASTOR_przemysl4_whitepaper.pdf.

Astor (2017). Engineer 4.0® (Not) ready for changes? Astor Whitepaper, from https://www.astor.com.pl/downloads/pliki/ASTOR_Whitepaper_Engineer40_Not_ready_for_changes_2019.pdf.

Astor (2019). Finanse Przemystu 4.0 Jak inwestować i wygrywać w rewolucji technologicznej? [Finance 4.0. How to invest and win in the technological revolution?]. Astor Whitepaper, from https://www.astor.com.pl/o-nas/artykuly/csr/10382-nowa-wizja-finansow-wprzemysle-4-0-wysoka-rekomendacja-astor-dla-strategii-win-win-w-projektach-inwestycyjnych-branzy-produkcyjnej.html.

Bałandynowicz-Panfil, K. (2019). Methodology of Research on Older Consumers - a Systematic Literature Review. Rozprawy Społeczne, $13,(4), 70-82$.

Barreto, L., Amaral, A., \& Pereira, T. (2017). Industry 4.0 implications in logistics: an overview. Procedia Manufacturing, 13, $1245-1252$. DOI: $10.1016 /$ j.promfg.2017.09.045.

Batkovskiy, A.M., Leonov, A.V., Pronin, A.Y., Semenova, E.G., Fomina, A.V., \& Balashov, V.M. (2019). Sustainable development of Industry 4.0: the case of high-tech products system design. Entrepreneurship and Sustainability Issues, 6 (4), 1823-1838. DOI: http://doi.org/10.9770/jesi.2019.6.4(20).

Bendkowski, J. (2017). Zmiany w pracy produkcyjnej w perspektywie koncepcji "Przemysł 4.0" [The Impact of Industry 4.0 on Production Work]. Zeszyty Naukowe. Organizacja i Zarzadzanie / Politechnika Ślaska, 112, 21-33. DOI: 10.29119/1641-3466.2017.112.2.

Benzies, K.M., Premji, S., Hayden, K.A., \& Serrett, K. (2006). State-of-the-Evidence Reviews: Advantages and Challenges of Including Grey Literature. Worldviews Evid Based Nurs, 3 (2), 55-61. DOI: https://doi.org/10.1111/j.1741-6787.2006.00051.x. 


\section{ENTREPRENEURSHIP AND SUSTAINABILITY ISSUES}

ISSN 2345-0282 (online) http://jssidoi.org/jesi/ 2020 Volume 8 Number 1 (September) http://doi.org/10.9770/jesi.2020.8.1(77)

Booth, A., Sutton, A., \& Papaioannou, D. (2016). Systematic Approaches to a Successful Literature Review. Second Edition. Los Angeles, London, New Delhi, Singapore, Washington DC, Melbourne: SAGE Publications.

Castelo-Branco, I., Cruz-Jesus, F., \& Tiago, O. (2019). Assessing Industry 4.0 readiness in manufacturing: Evidence for the European Union. Computers in Industry, 107, 22-32. DOI: https://doi.org/10.1016/j.compind.2019.01.007.

Chiarello, F., Trivelli, L., Bonaccorsi, A., \& Fantoni, G. (2018). Extracting and mapping industry 4.0 technologies using wikipedia. Computers in Industry, 100, 244-257. DOI: https://doi.org/10.1016/j.compind.2018.04.006.

Chui, M., Löffler, M., \& Roberts, R. (2010). The Internet of Things. The McKinsey Quarterly, 2 (47), 1-9.

Columb, M.O., \& Lalkhen, A.G. (2005). Systematic reviews \& meta-analyses. Current Anaesthesia \& Critical Care, 16 (6), $391-394$.

Dmowski, J., Jędrzejewski, M., Libucha, J., Owerczuk, M., Suffczyńska-Hałabuz, N., Pławik, K., Iwasieczko, M., \& Kowalska, I. (2016). Przemyst 4.0 PL. Szansa czy zagrożenie dla rozwoju innowacyjnej gospodarki? [Industry 4.0 PL. An opportunity or a threat to the development of an innovative economy?]. Warszawa: The Boston Consulting Group.

European Commission (2008). Regulation (EC) No 294/2008 of the European Parliament and of the Council of 11 March 2008 establishing the European Institute of Innovation and Technology, from https://eur-lex.europa.eu/legalcontent/EN/TXT/PDF/?uri=CELEX:32008R0294\&from=EN.

European Commission (2010a). Europe 2020. A European strategy for smart, sustainable and inclusive growth, Communication from The Commission. Brussels, from https://eur-lex.europa.eu/legal-content/EN/TXT/PDF/?uri=CELEX:52010DC2020\&from=en.

European Commission (2010b). Communication from the Commission to the European Parliament, the Council, the European Economic and Social Committee and the Committee of the Regions: An Integrated Industrial Policy for the Globalisation Era Putting Competitiveness and Sustainability at Centre Stage. Brussels, from https://eur-lex.europa.eu/LexUriServ/LexUriServ.do?uri=COM:2010:0614:FIN:EN:PDF.

European Commission (2013). Regulation (EU) No 1292/2013 of the European Parliament and of the Council of 11 December 2013 amending Regulation (EC) No 294/2008 establishing the European Institute of Innovation and Technology, from https://eurlex.europa.eu/legal-content/EN/TXT/PDF/?uri=CELEX:32013R1292\&from=EN.

European Commission (2017). Communication from the Commission to the European Parliament, the European Council, the Council, the European Economic and Social Committee and the Committee of the Regions and The European Investment Bank. Investing in a smart, innovative and sustainable Industry A renewed EU Industrial Policy Strategy. Brussels, from https://eurlex.europa.eu/resource.html?uri=cellar:c8b9aac5-9861-11e7-b92d-01aa75ed71a1.0001.02/DOC_1\&format=PDF.

European Commission (2018a). Regulation of the European Parliament and of the Council establishing Horizon Europe - the Framework Programme for Research and Innovation, laying down its rules for participation and dissemination. Brussels, from https://eurlex.europa.eu/resource.html?uri=cellar:b8518ec6-6a2f-11e8-9483-01aa75ed71a1.0001.03/DOC_1\&format=PDF.

European Commission (2018b). Council Regulation establishing the Research and Training Programme of the European Atomic Energy Community for the period 2021-2025 complementing Horizon Europe - the Framework Programme for Research and Innovation. Brussels, from https://eur-lex.europa.eu/resource.html?uri=cellar:683ead8d-6a31-11e8-9483-01aa75ed71a1.0001.03/DOC_1\&format=PDF.

European Commission (2018c). Communication from the Commission to the European Parliament, the European Council, the Council, the European Economic and Social Committee and the Committee of the Regions. A renewed European Agenda for Research and Innovation Europe's chance to shape its future. Brussels, from https://eur-lex.europa.eu/legalcontent/EN/TXT/PDF/?uri=CELEX:52018DC0306\&from=EN.

European Commission (2018d). VentureEU: €2.1 billion to boost venture capital investment in Europe's innovative start-ups. Press release IP/18/2763, from https://ec.europa.eu/commission/presscorner/detail/en/IP_18_2763.

European Commission (2019a). Proposal for a Regulation of the European Parliament and of the Council on the European Institute of Innovation and Technology (recast). Brussels, from https://eur-lex.europa.eu/resource.html?uri=cellar:1da38baf-be71-11e9-9d0101aa75ed71a1.0009.02/DOC_1\&format=PDF. 


\section{ENTREPRENEURSHIP AND SUSTAINABILITY ISSUES}

ISSN 2345-0282 (online) http://jssidoi.org/jesi/ 2020 Volume 8 Number 1 (September) http://doi.org/10.9770/jesi.2020.8.1(77)

European Commission (2019b). Annexes to the Proposal for a Regulation of the European Parliament and of the Council on the European Institute of Innovation and Technology (recast), from https://ec.europa.eu/education/sites/education/files/document-library-docs/annexesproposal-regulation-eit.pdf.

European Commission (2019c). Proposal for a Decision of the European Parliament and of the Council on the Strategic Innovation Agenda of the European Institute of Innovation and Technology (EIT) 2021-2027: Boosting the Innovation Talent and Capacity of Europe, from https://ec.europa.eu/education/sites/education/files/document-library-docs/proposal-decision-eit-2021-2027.pdf.

European Commission (2019d). Annex to the Proposal for a Decision of the European Parliament and of Council on the Strategic Innovation Agenda of the European Institute of Innovation and Technology (EIT) 2021-2027: Boosting the Innovation Talent and Capacity of Europe, from https://ec.europa.eu/education/sites/education/files/document-library-docs/proposal-decision-eit-2021-2027-annex.pdf.

European Commission (2019e). Commission Staff Working Document Impact Assessment Accompanying the document Proposal for a Regulation of the European Parliament and of the Council on the European Institute of Innovation and Technology (recast) and Proposal for a Decision of the European Parliament and of the Council on the Strategic Innovation Agenda of the European Institute of Innovation and Technology (EIT) 2021-2027: Boosting the Innovation Talent and Capacity of Europe, from https://ec.europa.eu/education/sites/education/files/document-library-docs/impact-assessment-swd-330-final.pdf.

European Commission (2019f). Proposal for a Decision of the European Parliament and of the Council on the Strategic Innovation Agenda of the European Institute of Innovation and Technology (EIT) 2021-2027: Boosting the Innovation Talent and Capacity of Europe, from https://ec.europa.eu/education/sites/education/files/document-library-docs/proposal-decision-eit-2021-2027.pdf.

European Commission (2019g). Orientations towards the first Strategic Plan for Horizon Europe, from https://ec.europa.eu/info/sites/info/files/research_and_innovation/strategy_on_research_and_innovation/documents/ec_rtd_orientations-hestrategic-plan_122019.pdf.

European Institute of Innovation and Technology (2019). European Commission proposes EIT strategy for 2021-2027, from https://eit.europa.eu/news-events/news/european-commission-proposes-eit-strategy-2021-2027.

Gajdzik, B., \& Grabowska, S. (2018). Leksykon pojęć stosowanych w przemyśle 4.0 [Lexicon of Terms Useing in Industry 4.0]. Zeszyty Naukowe. Organizacja i Zarządzanie / Politechnika Śląska, 132, 221-238. DOI: 10.29119/1641-3466.2018.132.14.

Gimenez, C., \& Tachizawa, E. (2012). Extending sustainability to suppliers: a systematic literature review. Supply Chain Management: An International Journal, 17 (5), 531-543.

Hermann, M., Pentek, T., \& Otto, B. (2015). Design Principles for Industrie 4.0 Scenarios: A Literature Review. Dortmund (Germany) Technische Universität. Working Paper 01.

Issa, A., Hatiboglu, B., Bildstein, A., \& Bauernhansl, T. (2018). Industrie 4.0 roadmap: Framework for digital transformation based on the concepts of capability maturity and alignment. Procedia CIRP, 72, 973-978. DOI: https://doi.org/10.1016/j.procir.2018.03.151.

Levy, Y., \& Ellis, T.J. (2006). A systems approach to conduct an effective literature review in support of information systems research. Informing Science Journal, 9, 181-212.

Liao, Y., Deschamps, F., Loures, E.F.R., \& Ramos, L.F.P. (2017). Past, present and future of Industry 4.0 - a systematic literature review and research agenda proposal. International Journal of Production Research, 55 (12), 3609-3629. DOI: http://dx.doi.org/10.1080/00207543.2017.1308576.

Lu, Y. (2017). Industry 4.0: A survey on technologies, applications and open research issues. Journal of Industrial Information Integration, 6, 1-10. DOI: https://doi.org/10.1016/j.jii.2017.04.005.

McKinsey Digital (2016). Industry 4.0 after the initial hype. Where manufacturers are finding value and how they can best capture it, from https://www.mckinsey.com/ /media/mckinsey/business\%20functions/mckinsey\%20digital/our\%20insights/getting\%20the\%20most\%20out \%20of\%20industry\%204\%200/mckinsey_industry_40_2016.ashx.

Młody, M. (2019). Lęk technologiczny jako patologia organizacyjna w dobie czwartej rewolucji przemysłowej [Technophobia as Organizational Pathology in the Age of the Fourth Industrial Revolution]. Studia i Prace Kolegium Zarządzania i Finansów / Szkoła Główna Handlowa, 175, 129-143. 


\section{ENTREPRENEURSHIP AND SUSTAINABILITY ISSUES}

ISSN 2345-0282 (online) http://jssidoi.org/jesi/ 2020 Volume 8 Number 1 (September) http://doi.org/10.9770/jesi.2020.8.1(77)

Młody, M., \& Weinert, A. (2020). Industry 4.0 in Poland: A Systematic Literature Review and Future Research Directions. In A. Zakrzewska-Bielawska, \& I. Staniec (eds). Contemporary Challenges in Cooperation and Coopetition in the Age of Industry 4.0. Cham (Germany): Springer Proceedings in Business and Economics.

Müller J., Dotzauer V., \& Voigt, K. (2017). Industry 4.0 and its Impact on Reshoring Decisions of German Manufacturing Enterprises. In C. Bode, R. Bogaschewsky, M. Eßig, R. Lasch, \& W. Stölzle (eds). Supply Management Research. Advanced Studies in Supply Management (pp. 165-179). Wiesbaden (Germany): Springer Gabler.

Niedbał, R., Wrzalik, A., \& Sokołowski, A. (2017). Czwarta rewolucja przemysłowa jako wyzwanie utrzymania konkurencyjności przedsiębiorstwa [Fourth Industrial Revolution as a Challenge to Maintain Enterprise Competitiveness]. Marketing i Rynek, 7(CD), 557570 .

Oesterreich, T.D., \& Teuteberg, F. (2016). Understanding the implications of digitisation and automation in the context of Industry 4.0: A triangulation approach and elements of a research agenda for the construction industry. Computers in Industry, 83, 121-139. DOI: https://doi.org/10.1016/j.compind.2016.09.006.

Paprocki, W. (2016). Koncepcja Przemysłu 4.0 i jej zastosowanie w warunkach gospodarki cyfrowej [The Industry 4.0 concept and its application in the conditions of digital economy]. In J. Gajewski, W. Paprocki, \& J. Pieriegud (eds), Cyfryzacja gospodarki i społeczeństwa - szanse i wyzwania dla sektorów infrastrukturalnych [Digitization of the economy and society - opportunities and challenges for infrastructure sectors] (pp. 39-57). Gdańsk: Publikacja Europejskiego Kongresu Finansowego, Instytut Badań nad Gospodarką Rynkową Gdańska Akademia Bankowa. https://depot.ceon.pl/handle/123456789/11162.

Piccarozzi, M., Aquilani, B., \& Gatti, C. (2018). Industry 4.0 in Management Studies: A Systematic Literature Review. Sustainability, 10 (10), 3821. DOI: https://doi.org/10.3390/su10103821.

PwC (2016). Industry 4.0: Building the digital enterprise. Global Industry $4.0 \quad$ Survey, from https://www.pwc.com/gx/en/industries/industries-4.0/landing-page/industry-4.0-building-your-digital-enterprise-april-2016.pdf.

PwC (2017). Przemysł 4.0 czyli wyzwania współczesnej produkcji [Industry 4.0, or the challenges of modern production], from https://www.pwc.pl/pl/pdf/przemysl-4-0-raport.pdf.

Rowley, J., \& Slack, F. (2004). Conducting a Literature Review. Management Research News, 27 (6), 31-39.

Saniuk, S., \& Saniuk, A. (2017). Analiza sytuacji polskich przedsiębiorstw w sieciach przemysłowych w dobie Industry 4.0 [Analysis of the Situation of Polish Enterprises in Industrial Networks in Industry 4.0]. Nauki o Zarzadzaniu / Uniwersytet Ekonomiczny we Wroctawiu, 2 (31), 12-17. DOI: 10.15611/noz.2017.2.02.

Stolarczyk, A. (2017). Kapitał ludzki - szanse i wyzwania w kontekście rozwoju koncepcji Industrie 4.0 [Human capital - opportunities and threats in the light of the Industrie 4.0]. Nierówności Spoleczne a Wzrost Gospodarczy, 51, 73-81. DOI: 10.15584/nsawg.2017.3.6.

Szatlach, M.E. (2018). Główne założenia procesu "unowocześniania" polityki spójności po 2020 r. [The Main Assumptions of the "Modernization" of Cohesion Policy After 2020]. Zeszyty Naukowe. Organizacja i Zarządzanie / Politechnika Śląska, 129, 595-603. DOI: $\underline{10.29119 / 1641-3466.2018 .129 .43 .}$.

Wilkinson, C., Allinson, R., Leather, J., \& Healy, A. (eds.) (2017a). Evaluation of the European Institute of Innovation and Technology (EIT). Final Report. Luxembourg: Publications Office of the European Union, from https://ec.europa.eu/education/sites/education/files/document-library-docs/finalreport_eitinterimevaluation.pdf.

Wilkinson, C., Allinson, R., Leather, J., \& Healy, A. (eds.) (2017b). Evaluation of the European Institute of Innovation and Technology (EIT). Annexes. Luxembourg: Publications Office of the European Union, from https://ec.europa.eu/education/sites/education/files/document-library-docs/finalreport_eitinterimevaluation_annexes.pdf. 


\section{ENTREPRENEURSHIP AND SUSTAINABILITY ISSUES}

ISSN 2345-0282 (online) http://jssidoi.org/jesi/ 2020 Volume 8 Number 1 (September) http://doi.org/10.9770/jesi.2020.8.1(77)

\section{Ackowledgement}

The article is the result of the researches performed, partially financed by the University of Zielona Góra, within the competition called Small Grants.

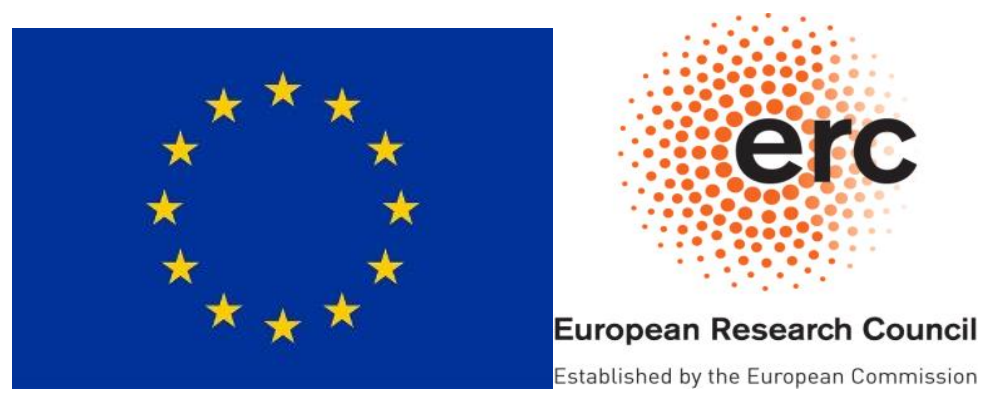

Joanna WYRWA $(\mathrm{PhD})$ is the Assistant Professor of Faculty of Economics and Management, University of Zielona Góra, Poland. She concentrates her research interests on the issues related to the creating innovations. She is the author and coauthor of over 100 academic publications. She is actively working towards economic practice. She disseminates the results of these research projects and performed at scientific conferences, and by publishing articles in academic notebooks at universities as well as in academic journals. She has received several awards for my achievements in academic research, particularly for the series of publications. She is a member of the Polish Economic Society and editor of the Scientific Journal of Polish Economic Society in Zielona Gora. Research interests: macroeconomics, innovation, labour market, social capital.

ORCID ID: orcid.org/0000-0003-0837-6590

Make your research more visible, join the Twitter account of ENTREPRENEURSHIP AND SUSTAINABILITY ISSUES:

@Entrepr69728810

Copyright (C) 2020 by author(s) and VsI Entrepreneurship and Sustainability Center

This work is licensed under the Creative Commons Attribution International License (CC BY).

http://creativecommons.org/licenses/by/4.0/

c) (i) Open Access 